\title{
From Industrial Heritage to a Regional Development Core in the 20th Century: The Case of Ilha Solteira
}

\author{
Mônica Peixoto Vianna \\ Department of Architecture and Urbanism, UNIT (Tiradentes University Center), Maceió 57037-030, Brazil
}

\begin{abstract}
The article deals with the built experience by the CESP (São Paulo's Electricity Company) in Urubupungá Complex, during 1950s and 1960s, with concomitant construction of urban centers — an provisional in Jupiá and another permanent in Ilha Solteira-with accommodation for singles, working villages and residences for technicians and engineers. The city of Ilha Solteira implanted permanently was an intermediate form of organization between the camp of Jupiá and the structure of a city, with a slightly more open community in which the citizens were still quite protected by the company. This study aims to describe the planning and the process of opening the core of Ilha Solteira, through non participant observation field work and research literature on the topic of its conversion into town and the attempt to create a pole of development for the region through their characteristic urban design plan: linear city and radio concentric city. However, the transformation of Ilha Solteira on a city in the early $1980 \mathrm{~s}$ happened in the crisis of developmentalism and authoritarianism, in a time when the CESP no longer wished to transform Ilha Solteira in pole of regional development, but in a city able to stand alone, because their maintenance costs become prohibitive.
\end{abstract}

Key words: CESP, development core, Ilha Solteira.

\section{Introduction}

The origin of Urubupungá Hydroelectric Complex is in the agreement established in 1951 between the governments of the States of São Paulo, Goiás, Mato Grosso, Minas Gerais, Paraná, Santa Catarina and Rio Grande do Sul. This agreement gave origin to the CIBPU (Interstate Commission Basin Paraná-Uruguay) in 1952. In 1955, the consulting firm Edisonbrás, the Brazilian subsidiary of Edison from Milan (Italy), has been contracted by CIBPU to prepare drafts and preliminary studies on the use of the region.

In May of 1957, the CIPBU has obtained from the federal government a concession for the State of São Paulo seizing the hydraulic energy of the stretch of the Paraná River. However, only in the government of President Carvalho Pinto that São Paulo State began to pay special attention to the design of Urubupungá, including it in its PAGE (State Government's Action

Corresponding author: Mônica Peixoto Vianna, Ph.D., professor, research fields: regional planning, company towns, industrial heritage and history of hydroelectric sector. E-mail: monica_vianna@yahoo.com.
Plan) between 1959 and 1963. Due to difficulties for its organization, only in January of 1961, the CELUSA (Power plants of Urubupungá S.A.) was created which was charged with studying, designing, setting up and operating the production, processing, transmission and distribution of electric power systems, and to promote the use of other occurrences in the Paraná river and its tributaries.

The CELUSA should build dams of accumulation, in order to regularize the flow of rivers, as also construct locks for navigation, irrigation works, drainage and protection of marginal lands. Regarding the studies, it was authorized to draw up plans and programs for economic development and guide the private sector in the implementation of economic activities in area served by the company.

Taking advantages of a series of jumps in the Paraná and Tietê rivers, Urubupungá Complex consisted, at the time of its construction, the largest hydroelectric complex in the southern hemisphere.

The planning for Urubupungá was prepared by the engineer Ernest Robert C. Mange and his team, the 
EMAK $^{1}$, between $1957-1960$ to address the housing needs provided by the construction of the hydroelectric power plants of Jupiá and Ilha Solteira. Jupiá represented the first significant experience of planning the deployment of manpower to build hydroelectric power plants. One of the most important aspects related to the complex was concomitant construction of urban centers, on a temporary in Jupiá and one permanent in Ilha Solteira, with accommodation for singles, working villages and homes for technicians and engineers [1].

\section{The Pilot Village and the Operators Center}

The hydroelectric plant of Jupiá, which is current named as Engineer Souza Dias, is located on the Paraná River between the towns of Castilho and Andradina (both in Sao Paulo State) and Três Lagoas (Mato Grosso do Sul State).

The region of Jupiá, as a consequence of the type of colonization developed in this part of state territory, remained sparsely populated until the implementation of hydropower. It is known that the construction of large power plants in a region lacking the support of large urban centers requires the building of accommodation for singles, the workers' villages and facilities for the residence of machine operators.

The plant of Jupiá began operating its first genset in April 1969 and its works were completed in June, 1974. In December, 1966, CELUSA has been integrated into CESP (São Paulo's Electricity Company), which continued the construction of the plant. The villages from Jupiá were the urban centers built for the dam builders and for the operators of Jupiá plant.

The Vila Piloto (Pilot Village) was implanted in the State of Mato Grosso do Sul, $2 \mathrm{~km}$ from the

\footnotetext{
${ }^{1}$ Until 1968, the project office was known for EMAK, passing thereafter to officially call PLANEMAK (Planning Buildings and Cities S/C Ltda) which had for this project: Ernest Robert C. Mange (engineer); Ariaki Kato (architect), Fernando de Andrade and Veiga Norio Sakai (architects and group leaders); and Pascoal Brumatti (chief designer).
}

construction site of the Jupia plant and $3 \mathrm{~km}$ from the urban area of Três Lagoas. The buildings were made of wood, with brick pillars and ceramic tiles. It was designed as a temporary and closed company town and whose plan presented concepts of modern urban planning, stemming from theories of neighborhood unit and zoning. Built in 2 years, between late 1959 and 1962, the village had urban facilities such as schools, hospital, center for culture and leisure, city hall, parks and was expected to house 15,000 people. Its control mechanisms, used by CESP, featured a paternalistic performance (Fig. 1) [2].

The principles that guided this project were the creation of an autonomous residential complex, with a program that would fully meet the everyday life of families. The concern with the architectural design of dwellings could be perceived by some proposed solutions as the space of dwellings, concern about environmental comfort, easy maintenance and location around the square and the sports recreation area. The radio concentric plan designed strongly alleged that the sense of community that was built on the basis of the program and neutralized human coldness

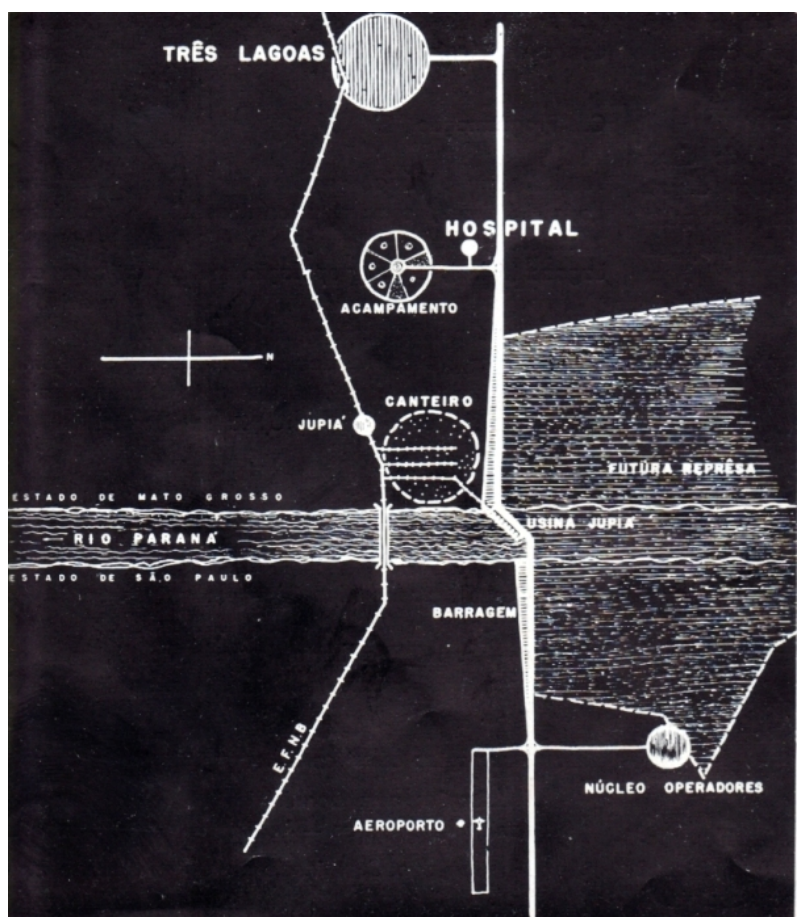

Fig. 1 Scheme of urban implantation of Pilot Village, Operators Center and hydroelectric plant of Jupiá [4]. 
contained in artificial and temporary, and the spatial monotony imposed by housing standardization. Mange adopted the concept of neighborhood unit with their equipments, however, the necessary adaptations and additions required by the real context of the issue were made. Likewise, the use of the expression "core" by the engineer reveals adherence to debates occurring during the CIAMs (International Congresses of Modern Architecture) in the second post World War [3].

The works of demobilization of these places were carried between 1969 and 1970. The village was partially disassembled: a quarter of the plan area, club and some residences, was preserved for use of the Army, a military unit based in Três Lagoas. With the start of construction of the urban core of Ilha Solteira, they proceeded to the removal of wooden and usable materials. Then, the houses were scrapped and sold, getting buyers forced to do the demolition and site cleanup. The urban facilities like hospital, schools, parks and some of the buildings were transferred to the municipal center of Três Lagoas which implemented an industrial district, thus envisaging in the final remnant of the camp (Fig. 2).

In the edges of the Jupiá reservoir, in the ground of São Paulo State, the second village was built, the Vila dos Operadores (Operators Center), with brick houses that were intended for the technical and administrative staff needed to operate the plant of Jupiá. The characteristics of this small cluster, designed by the EMAK, were also close to the core concepts of company towns, with some particular characteristics.

The state was the owner, at first, through CELUSA, and then the CESP. There was a kind of charter that dictated the rules: the content was equivalent to the standards of a condominium, with the difference that punishment involving fines and, in extreme cases, loss of employment. The priority was to hire employees with family: the number of dwellings would be 200, much lower than the Village Pilot. If there were single operators, they would be placed in the hotel-pension.
However, the number of dwellings built has not reached the planned, with the largest number of occupancy were around 500 people (Fig. 3) [2].

At the end of the works, the houses were sold both to new residents as to the CESP staff that chose to remain there, the old Vila dos Operadores characterized currently as a gated community [4].

\section{New City}

The hydroelectric plant of Ilha Solteira, the second stage of Urubupungá Complex, was established as one of the largest hydroelectric projects of the time. It was located between the cities of Pereira Barreto (SP) and Selvíria (MS), and its first generator went into operation in 1973 and the last in 1978.

The CCCC (Buildings and Trade Camargo Corrêa) won the tender for the construction of Ilha Solteira. Ernest Mange and Kato Ariaki were again contracted by the EMAK to carry out the planning of this new stage of complex of Urubupungá. To them, the projects were ordered for organizing the construction

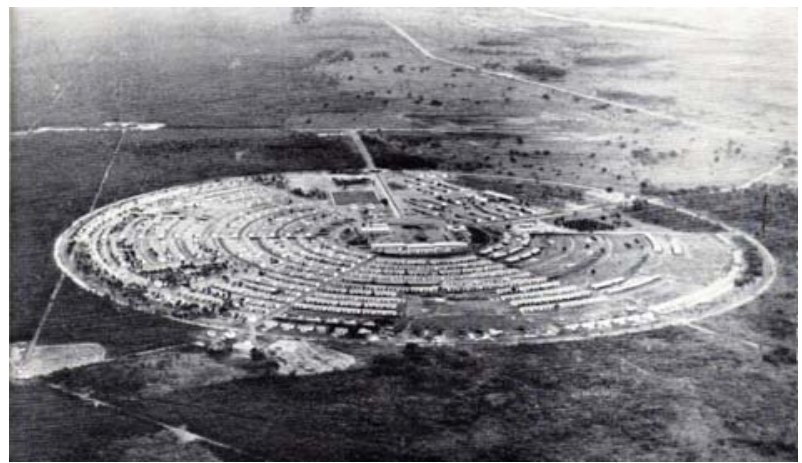

Fig. 2 Pilot Village of Jupiá [4].

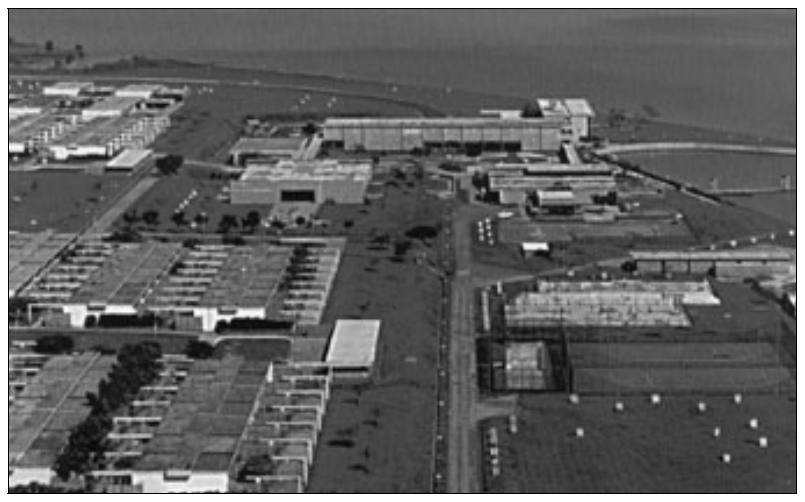

Fig. 3 The Operators Center of Jupiá [4]. 
site, the substation, the urban core and planning the new road system. The technical design of the hydroelectric plant was carried out by THEMAG Engineering.

Ilha Solteira should meet the immediate requirement of installing the necessary manpower for the construction of the hydroelectric plant, but could also be planned to become a city. Therefore, their planning was flexible enough to scale all that was required to run the city in its first stage of "camp", meeting the basic needs of a population of 35,000 inhabitants, and enable its progressive expansion in accordance with the development future of the city [5].

The region near the hydroelectric plant had an unfavorable urban network with cities very distant from each other. This condition helped the company decide to build an urban core with permanent character that would allow transfer to the region the improvements made with the work. Other arguments were placed together by the proponents of this position, as the fact that the company would expend a similar manner to the construction of a provisional core, but now reducing the social cost of the work to be prevented from progressive destruction of the core and all the facilities that this would bring to the region [6].

The Urubupungá Complex can be considered as the first attempt at comprehensive planning of the establishment of manpower necessary to the construction and operation of hydroelectric power plants in Brazil.

The beginning of the interventions in Ilha Solteira occurred only in 1966, when all the workers still lived in the Village Pilot. In 1968, with the completion of Jupiá plant, the transfer of staff to the new city began which, at that time, was still a camp in the works. In 1971, the core reached its maximum population, estimated at about 32,000 inhabitants, with school groups, gym and educational center for adults, vocational training, three hotels, club, shops, services and a hospital. The initial design provided for a maximum population of 53,000 inhabitants, but already in 1973 the population grew to 18,000 inhabitants, due to the decrease caused by the termination of the main work. The designers had to adapt the master plan and balance the deployment with the gradual occupation within a very short time (Fig. 4).

The idea was that the place could become a center of economic development in the region through the insertion of industries in a predominantly traditional country life. However, this would not be sufficient to integrate the city in its regional context: the integration would be affected only by the establishment of relations of production, trades and services, stimulating the regional agriculture and the establishment of a road network that facilitates communication. Subsequently, the planning was established taking into account these requirements and its zoning, sizing their equipment and providing all the functions that should be performed by the city.

In terms of urban layout, the model used was the linear city. The ideas were adapted to the circumstances. There was no great center for the association of this new core, as stipulated in the theory, and the city by itself would be the generator of the linear

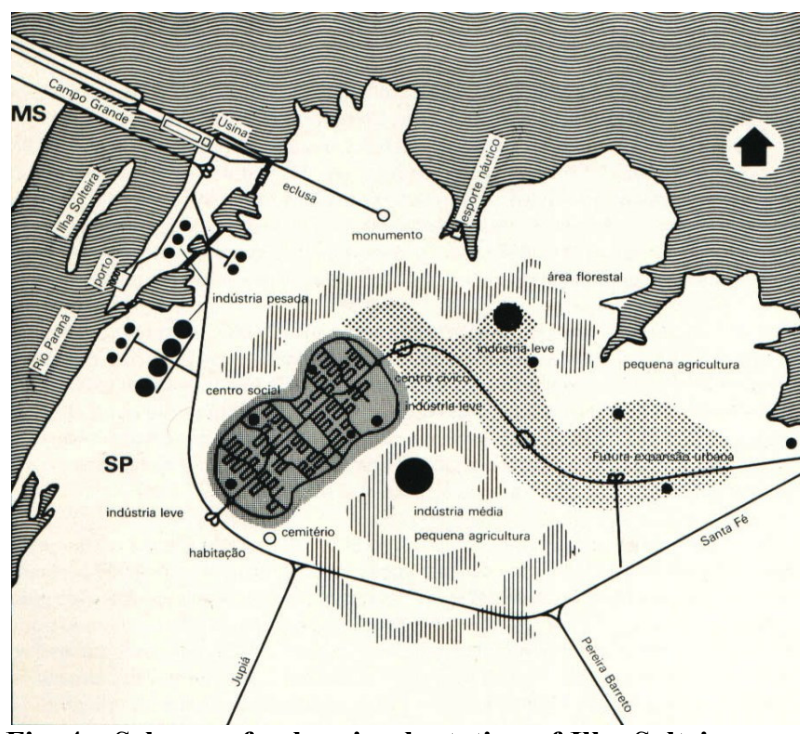

Fig. 4 Scheme of urban implantation of Ilha Solteira core [5]. 
city and over time, urban expansion would occur orderly manner. The proposal was to build the first stage along the road axis located in the hinge of the two highways linking the plant of Ilha Solteira to the city of Pereira Barreto and Três Lagoas [2].

The urban area was configured with linear development, that is, the core growth would be processed with the expansion of the urban area in the longitudinal direction. The longitudinal axis was called the Avenida Brazil Norte on one side of the communal center and Brazil Avenue South, on the other side. The transverse central axis that divides the core into northern and southern areas and this area would become a reference. In the geometric center of the axis, a large water tank was lifted up, $33 \mathrm{~m}$ tall and is a monument of the city, around which was located the "core" of the city-theme CIAM VIII, 1951-with the administration building, the gymnasium, the technical schools, church, hotel, telephonic, the post and the clerk cultural center. Along central avenue, symmetrically, both in the north and in the south, the constructions were distributed in the areas intended for trade, to the market, fairs, to school groups, banks and hotels (Fig. 5).

The zoning defined three major areas: urban, heavy

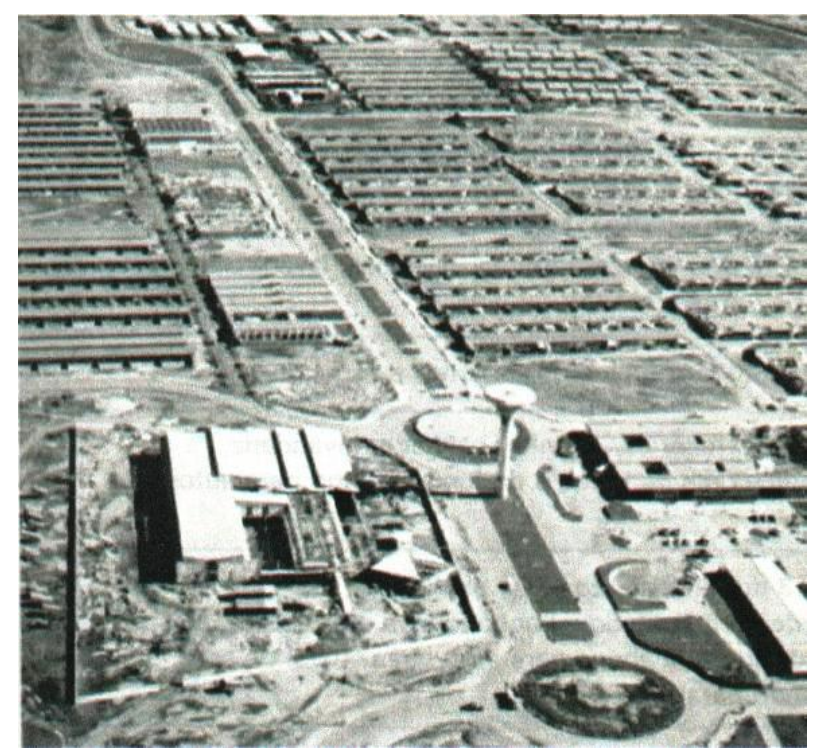

Fig. 5 Ilha Solteira core [5]. industry and the green belt (forest area and small farms). The urban area was divided into housing and equipment, which in turn was divided into four sectors: Sector 1 (leisure and recreation through a generous system of parks and squares); Sector 2 (schools, shops and public and private services, all located along the longitudinal axis); Sector 3 (central zone, where the communal center, core were located and distributed in the transverse axis in the center of the nucleus and entailed the building of the city administration, road, specialized trade, cultural center, cinemas, theater, square, gymnasium, technical schools, church, hotel, building telephone, postal, notary, etc.); and Sector 4 (small businesses and service providers located along the perimeter road). The transverse central axis that divided the core into northern and southern area and this area has become a reference.

The road plan was simple and functional in tune with the proposals in the planning of neighborhood units and garden cities. It was divided into five types: longitudinal axis; perimeter road (which were the main and larger routes); set of routes of entry (intended for average circulation of vehicles); set of lanes (low vehicle traffic in residential areas); and number of alleys.

The deployment was initiated from the central area with a hotel, a school, an administration office, some housing and accommodation for singles workers. Along the transverse axis which bisects the central avenue, the accommodation of the unmarried population was located, which relied on sporting and dining facilities.

At one end of the central axis-tracked, a hospital was located, and the other, the other social and recreational equipments, consisting of clubs, sports center, zoo, area parks, fairs, circuses etc.. The residential area, formed by symmetrical blocks, was composed of houses of the same level that obeyed criteria that grouped the population into six levels of occupational categories (as used to occur in nuclei created by factories). More close to the residences, 
along the boulevards, and the areas between households, zones of community facilities, in order to facilitate their access and use, the first need equipments were located. The area for the installation of light industry and equipment supply and maintenance of vehicles, and specialized public services is located between residential areas and the perimeter promenade. Thus, the notion of neighborhood unit can be seen here by the distribution of buildings across uses, and the location of the school and the daycare center position.

The insulation condition of the city, along with a long work schedule and local life, imposed a definition of autonomy that would allow him to have administrative general equipment, represented by public utilities such as preventive policing, security, catering, school districts, medical assistance, transportation, communications, social services, etc. [3].

The experience of Urubupungá represented the practical and real possibility of planning the picture of the life of contingent labor required for the execution of large engineering projects. Despite the diminutive term and relatively small resources, it was possible, according to the engineer, to look with dedication of the human side in this type of work and apply the use of conscious planning [3].

\section{Regional Integration}

Ilha Solteira was located in a strategic position in the center of a fertile region and its development had been intense, and should definitely be consolidated when the dams become road bridges and direct communication between São Paulo and Mato Grosso do Sul states should be also established.

The development of the city, in a gradual and controlled evolution, was the major concern of technicians who planned and believed that its evolution, in general, would be processed in four distinct phases: an initial deployment; a second characterized by a situation of camp-city; a third one of city-camp; finally, the last of the city. In consequence, the broad lines of general policy of the CESP, opposite the town of Ilha Solteira, can be summarized in the creation of an urban core to meet housing needs and services of the employees of CESP and contractors, creating conditions for the core to establish as a permanent city by drawing up a master plan and proper urban plan in adequacy of administrative plans and programs to the characteristics of each phase of core life that camp would become an ordinary city [7].

Thus, the core of Ilha Solteira was intended to subsist after the completion of construction of the plant, constituting what used to be called pole of regional development, provided with conditions to provide high quality of life, thanks to perfect health conditions and care medical high standard. Its population was formed by a portion of the population of Jupiá which was transferred to this work and another group of people who came out of a "common liberal city" and went to Ilha Solteira due to the labor camp to trade or services, having been installed by company authorization, but without employment vinculum.

For an urban core with concurrent features of town and camp, it would be necessary to endow it with a broad and flexible administrative scheme, able to face various situations and allow for quick adjustments before unexpected situations. Thus, CESP equated the problem of implementation, organization and administrative functioning of the city through the establishment of an urban master plan and the creation of the AEIS (Special Administration of Ilha Solteira) [5].

The AEIS represented a new experience in terms of administration. Its main functions could be divided in implementing urban infrastructure, building housing and community facilities, administering those services, promoting community development, establishing mechanisms for guidance and social control, creating conditions for socio-economic development of the city, 
establishing relationships with state and federal agencies and authorities and worrying about the effects of the polarization of the town of Ilha Solteira in the region. The AEIS concern was mainly to create a structure that was valid to a city that, after his untying of CESP, becomes autonomous [5].

The hydroelectric plant was inaugurated in 1974, a period marked by the end of the so-called "economic miracle" in Brazil. Among the measures adopted, the followings were included: the installation of a unit of UNESP (São Paulo State University), the allocation of about 1,500 residences to house families of workers from other works of plants; the Technical Training Center of CESP in 1978, focusing technical training and CESP; the LCEC (Central Laboratory of Civil Engineering) which had its origin in 1961, with CELUSA; and design of the "green belt" which aimed to provide access to land and supply of agricultural products to the region, creating jobs and new sources of energy.

Measures to transform the urban core in an open city started to be implemented since 1980, as the registration and the sale, in the real estate property market of the city, the dwellings and commercial buildings to private traders and shops, as well as the land industries. Then, Ilha Solteira which began the process to assume its own identity with its urban space would transform according to the different activities of its residents [4].

The realization of the transformation of Ilha Solteira on a city in the early 1980s happened in the crisis of developmentalism and authoritarianism, in a time when the CESP no longer wished to transform Ilha Solteira in pole of regional development, but in a city able to stand alone, because their maintenance costs become prohibitive [8].

Thus, the CESP adopted a more effective policy of decoupling only between 1980 and 1985, through the sale of houses and collection of infrastructure services, as in practice, made the core a district of the city of Pereira Barreto. Ilha Solteira, as a company town, lasted

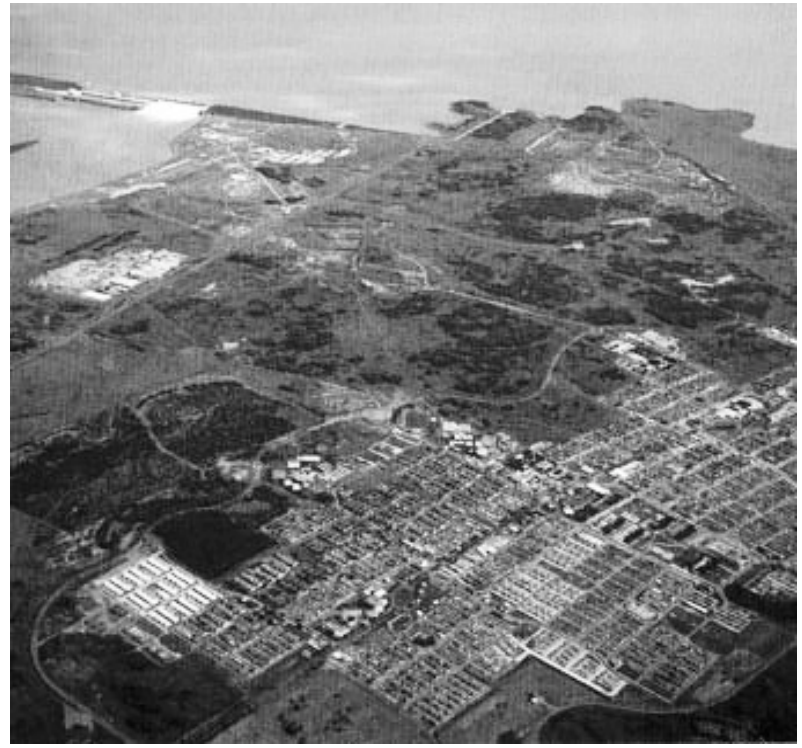

Fig. 6 Ilha Solteira City [1].

until 1992, when a referendum led to the creation of the council which opened real perspectives for autonomy (Fig. 6).

The process of emancipation of Ilha Solteira (1986-1992) took place amid the economic crisis of hyperinflationary nature. If economic conditions do not allow the deployment of dreaming polo from the 1960s, political conditions enabled the establishment of a municipality reasonably sized, but excessively linked to CESP and very little to the region, for which it has become a true enclave. Ilha Solteira, hydroelectric plant or city, according to the author, was not able to promote regional development that the ideologies of welfare advocated [8].

\section{Conclusions}

In terms of planning model adopted in the Urubupungá Complex, it was able to identify the regional scope starting from the boundary of the watershed and the election of Ilha Solteira as a hub for regional development. The city of Ilha Solteira implanted permanently and it was an intermediate form of organization between the camp, seen in Jupiá, and the structure of a city, with a slightly more open community in which the citizen was still quite protected by CESP. 
The urbanism adopted evolved the concept of core and residential camp work to create a structure that could house a city in the future to serve as a vector for development of an undeveloped region. In this project, methods for manufacturing cores, social hierarchy, program, etc., lived together with procedures established by modern urbanism, concept of neighborhood unit, linear city, radio concentric city, functional division of space and hierarchy of the road system.

The importance of these experiences can be perceived also to serve as a starting point for social problems awareness, economics and politicians involved in the construction of house workers to be dismantled, as the Village Pilot, or permanent cities but that are still deeply subordinate to the company as in Ilha Solteira.

At the end of the 1980s, Ilha Solteira had already $100 \%$ of their infrastructure installed. Since its emancipation, the population has remained constant in recent years, around 25,000 inhabitants in 2012, and the great challenge of the city hall and the state government of São Paulo has organized the existing heritage to activate the expansion of business and job opportunities, and used the entire deployed infrastructure and the change of natural conditions with the presence of people with technical and university education to move the development of the city and its region in a sustainable way.

\section{References}

[1] Tsukumo, N. M. J. 1994. Architecture at CESP. São Paulo: CESP.

[2] Araújo, C. G. 2004. "Arquitetura e Cidade na Obra de Ernest de Carvalho Mange, São Carlos." Master thesis, University of São Paulo. (in Portuguese)

[3] Vianna, M. P. 2006. "Workers Housing from CESP: The Dismount Process." Master thesis, Universidade de São Paulo.

[4] CESP. 1970. Ilha Solteira. Experiência de Implantação de uma Cidade. Ilha Solteira: AEIS (Special Administration of Ilha Solteira). (in Portuguese)

[5] CESP. 1988. Ilha Solteira: A Cidade e a Usina, Fascículos de História da Energia Elétrica em São Paulo. São Paulo: CESP. (in Portuguese)

[6] Vianna, M. P. 2012. "From the Building to the Urban Layout: The Experience of Integrated Regional Planning in CESP, São Carlos." PhD thesis, Universidade de São Paulo.

[7] Mange, E. R. C. 1963. "Planejamento em Urubupungá, São Paulo." PhD thesis, University of São Paulo. (in Portuguese)

[8] Froelich, G. M. 1999. "Ilha Solteira: Uma História de Riqueza e Poder (1952-1992), São Paulo.” PhD thesis, University of São Paulo. (in Portuguese) 